\title{
Characteristics of a School, Community and Family Partnership to Increase Parental Involvement in Learning at Rural Multigrade Schools
}

\section{Dr Nicolaas Van Loggenberg Venter}

Cape Peninsula University of Technology

Email: nidiventer@webmail.co.za

\section{Dr Jurie Joubert}

Email: joubertjurie36@gmail.com

\section{Prof. Rajendra Chetty}

Cape Peninsula University of Technology

Email: chettyr@cput.ac.za

\section{Doi:10.5901/mjss.2014.v5n23p1225}

\section{Abstract}

Parental involvement in learning through a school, community and family (SCAF) partnership programme is needed at rural multigrade schools in order to ultimately improve academic achievement. The internal and external challenges these schools and their parents face daily, however, are currently detrimental to parental involvement in learning. Lack of support, and inability of schools to design their own SCAF partnership programme, further hinder parental involvement in learning. This study aims to determine the product characteristics of a SCAF partnership programme that will support rural multigrade schools to develop their own practicable, contextual and effective strategies to improve parental involvement in learning. Although the process characteristics of such a programme are equally important, they are beyond the scope of this article. This study used a qualitative methodology through design-based research. Although the study comprised two phases, this article focuses on Phase Two. Phase One is beyond the scope of the article. In Phase Two, the sample comprised 26 parents and eight teachers from two randomly sampled rural multigrade schools in the Western Cape, South Africa. Data was collected through focus group interviews, observations, reports and logs at these schools in the Cape Winelands education district in the Western Cape. The findings indicate the product characteristics as: promoting partnerships with parents that lead to involving parents in learning; creating formal and informal opportunities for communication regarding learning; and utilising community and parents as resources to enrich children's learning. This study further indicates that parents and teachers need to focus on these characteristics and existing challenges in the multigrade milieu, when developing a SCAF partnership programme during a workshop. This will then lead to the development of practicable, contextual and effective strategies for that specific school.

Keywords: parental involvement, rural multigrade schools, SCAF partnership programme, product characteristics

\section{Introduction}

Worldwide, a growing number of educational institutions are focusing on the development of school, community and family (SCAF) partnership programmes to increase parental involvement in learning. Research has shown the positive influence of school, community and family partnerships on learners' academic achievements (Epstein \& Sheldon, 2006; Fan \& Chen, 2001; Henderson \& Berla, 1994; Henderson \& Mapp, 2002; Jeynes, 2003, 2005). It is a known fact that South African children are routinely underachieving (Bloch, 2009, p. 17), especially in rural areas (Bayat, Louw, \& Rena, 2014, p. 183). Rural schools, and specifically rural multigrade schools in South Africa, have little parental involvement (Venter, 2013, p. 2). The large number of rural multigrade schools and the nature of the challenges these schools and parents face exacerbate the lack of parental involvement. Twenty-seven percent of South African schools are considered rural multigrade schools (Education Policy Consortium, 2011, p. 18). If the challenges these schools face were considered while developing a SCAF partnership programme for rural multigrade schools, academic achievement might improve. Owing to physical and educational challenges, as well as economic factors, it is imperative that schools be supported in every possible way to increase academic achievement. Epstein (2009, p. 12), however, cautions that although most families care about their children, want them to succeed, and are eager to be good partners in education, 
and most teachers and administrators would like to involve families, many do not know how to build positive and productive SCAF partnership programmes effectively and affectively. A lack of knowledge about how to develop SCAF partnership programmes for rural multigrade schools in South Africa currently exists. Determining the product characteristics of a SCAF partnership programme to increase parental involvement in learning at rural multigrade schools is vital in the development of such programmes. Extensive academic research has explored the characteristics and dynamics of parental involvement through school, community and family partnerships (Epstein, 2011; Jeynes, 2011). Little is known, however, about the specific product characteristics of a SCAF partnership programme to increase parental involvement in learning at rural multigrade schools in particular. Past research has focused on SCAF partnership programmes as a blueprint for all types of schools to improve parental involvement in learning. There is a paucity of literature regarding a SCAF partnership programme specifically designed for rural multigrade schools. Consequently, we have an incomplete picture of the product characteristics of a SCAF partnership programme that could increase parental involvement in rural multigrade schools in South Africa.

Against this background, the purpose of this research is to answer the research question: 'What are the product characteristics of a practicable, effective, contextually based school, community and family partnership programme that increase parental involvement in learning at rural multigrade schools in South Africa?" This research identifies the product characteristics of a SCAF partnership programme for rural multigrade schools and relates them to practicable, effective strategies that increase parental involvement in learning. The findings of this research provide rural multigrade schools with key elements when developing a SCAF partnership programme. This article has four parts. First, it reviews extant literature relevant to rural multigrade schools and SCAF partnership programmes. Then the research methodology is presented and data analysis techniques are discussed. Next, findings are discussed and summarised. Finally, implications, limitations and directions for future research are offered.

\section{Parental Involvement in Learning through a SCAF Partnership Programme at Rural Multigrade Schools}

\subsection{Parental Involvement or School, Community and Family Partnerships, or Both?}

Parental involvement is a broad and complex multidimensional construct (Wandersman, Motes, Lindsay, Snell-Johns, Ford, \& Amaral, 2002). According to Van Wyk and Lemmer (2009, p. 8), a parent could be married or single, a relative (an older sibling, cousin, aunt or a uncle for example), a custodial grandparent, a legal guardian, a surrogate parent, a foster parent, a same-sex parent or even a group such as a commune or any other person who takes care of the child. Involvement in education is described as 'the willing and active participation of parents in a wide range of school and home-based activities' (Van Wyk \& Lemmer, 2009, p. 14). Epstein (2011, p. 43), however, argues that school, family and community partnerships are better terms than parental involvement to recognise that parents, educators and others in the community share responsibility for learners' learning. For different stakeholders in education, parental involvement, or a school, community and family partnership can be many things. Some may believe that parents are involved only in governance of the school and are therefore mainly responsible for the financial wellbeing of the school. Some see parental involvement as parents helping with school activities, fund raising or the coaching of a sport at school. Others might see parents as partners to educate learners. In this research, the aim is to engage parents in learning through willing and active participation (outcome) and the recognition that a partnership between school, family and community (method) plays a vital role in rural multigrade schools.

\subsection{The Context of Rural Multigrade Schools}

It should be asked why and how we need an increase in parental involvement in learning through a school, community and family partnerships at rural multigrade schools?

The term rural multigrade schools consist of rural and multigrade schools. Different views on the definition of 'rural' exist. The connotations of the word 'rural' in a developed country might differ from those in a developing country. In developing countries, small populations, agriculture and poverty are often synonymous with 'rural' (UNESCO, 2007). In this study, 'rural' is described as geographically isolated and situated outside the boundaries of urban areas.

Multigrade schooling is most often used in isolated rural areas of not only a developing country such as South Africa (Taole, 2014, p. 531), but also in developed countries (Education Policy Consortium, 2011:3). Little research has been captured on multigrade education in South Africa, although it is used widely. Multigrade schooling is a strategy to increase the educational opportunities of children in situations where, because of the limited size of the learner population, a teacher cannot be appointed for each grade of primary school. In a multigrade school, teachers manage two 
or more classes simultaneously: a single teacher may be responsible for all primary grades (Little, 1995, p. 4).

For this study, the definition of rural multigrade schools of Jordaan and Joubert $(2008, p .7)$ is considered the most appropriate. They conclude that in South Africa a rural multigrade school is:

- geographically isolated and situated outside the boundaries of urban areas; and/or

- characterised by learner-centred classrooms where at least two or more grades are taught. These learners have different abilities and levels and receive their education in one classroom with the same teacher for two or more years.

Multigrade schools in South Africa face huge challenges, such as physical and educational characteristics and economic factors. Multigrade schools are often isolated (Little, 2005, p. 5) and the majority are prevalent in remote rural and farming areas (Education Policy Consortium, 2011, p. 6). With an unemployment rate of 25.3 percent (Statistics South Africa, 2010), poverty is a massive challenge in rural areas. Challenges such as the lack of training, large classrooms and classroom management (Taole, 2014, p. 533) are widespread in rural multigrade schools. Resourcing and support are huge challenges: Education Policy Consortium $(2011$, pp. 26, 69) points out that the biggest struggle to provide quality education to rural communities has been to provide equitable resources, and lack of district support for multigrade teachers due to officials not trained in multigrade teaching. These internal challenges exist within the rural multigrade milieu. They are exacerbated by the external challenges that parents face, which include illiteracy and long working hours (Adendorf \& Ortell, 2011, p. 65; Boozaaier, 2008, p. 51; Venter, 2013, p. 3). These challenges, however, should not dampen parents' right to be involved in their child's education. Fuller (2008) and Amoateng, Richter, Makiwane, and Rama (2004) state that parents from low-income families show great interest in the success of their children and have a right to be involved in their education.

The inclusion of 'rural multigrade learners' is considered extremely important, owing to the human capital approach and rural transformation (UNESCO, 2012, p. i). The rationale for investing in education lies in the contribution that education can make to economic growth (Hanushek \& Wössmann, 2007). Parental involvement is one aspect of 'rural transformation'. Local studies indicate the dire lack of parental involvement at rural schools in South Africa. Hamunyela (2008) states that parental involvement is difficult to implement in rural schools owing to existing challenges, Adendorff and Ortell (2011, p. 65) observed at 126 farms in the Western Cape that little happens at home in an educational sense. Parents were either unable to help their children or seemed to be apathetic towards the educational and social needs of their children. Boonzaaier $(2008$, p. 385) reminds us that value of parents in rural multigrade schools is often underestimated. Therefore the lack of research on how to involve rural multigrade parents is evident.

Parental involvement at rural multigrade schools is, however, possible. Linking school with community enables teachers at multigrade schools to improve the quality and relevance of the education they are providing (Little, 1995, $p$. 240). In Colombia, the Escuela Nueva Model (Colbert de Arboleda, 2010, p. 22) and in India, the River Rishi Valley Project (Rao, 2010, p. 17), focus on the importance of parental and community involvement in multigrade classrooms. Little, Pridmore, Bajracharya, and Vithanapathirana (2006, p. 285) concur that parental involvement in Escuela Nueva is high, and that parents of pupils in the system help their children at home with learning. Blum and Diwan (2007, p. 49) note in their research on the Rishi Valley that one of the key factors in schools' improvement has been the active involvement of parents and communities. Parental involvement has also been encouraged in a range of activities such as conducting learning exercises with children, working as community teachers and advocates, providing help in organising classrooms and schools, and helping teachers in preparing teaching aids (Blum \& Diwan, 2007, p. 49). Parental involvement in learning through a SACF partnership programme is needed in South African rural multigrade schools. An important aspect of such a programme is to determine the specific product characteristics. If these product characteristics take into account the challenges rural multigrade schools face, a practicable, effective and context-based programme that increases parental involvement in learning should be the outcome.

\subsection{Characteristics of SCAF Partnership Programmes}

According to Epstein (2011, p. 26), certain perspectives on family - school relations are currently guiding researchers and practitioners in their thinking. Separate responsibilities stress the inherent incompatibility, competition, and conflict between families and schools (Epstein, 2011, p. 26). Rural multigrade schools find themselves in this domain not necessarily because of competition or conflict, but because of the large number of challenges rural multigrade schools and parents encounter in their specific and 'forced' context, which hinders parental involvement. Epstein (2011, p. 26) highlights co-operation, co-ordination and collaboration between families and schools, in order for schools to move towards a domain of shared responsibility. According to Jeynes (2011, p. 112), parental involvement programmes are school-sponsored initiatives; the direct result is that schools that strive for parental involvement often lead the way by 
identifying projects, needs, and goals and then telling parents how they can contribute (Ferlazzo, 2011, p. 12). Parents from rural multigrade schools need to develop a practicable and context-based school, community and family partnership programme. Within a partnership programme, it is possible to tap social, cultural and economic capital (Ho, 2009, p. 103) that exists in the community, at home and at school in the rural multigrade context. Determining the product characteristics of a SCAF partnership programme guides rural multigrade schools in their search for parental involvement.

Table 1 compares the product characteristics of Epstein's approach (USA), the Training and Development Agency for Schools (TDA) in the UK, and the International Step by Step Association (ISSA), which operates in central, eastern, and southeastern Europe and central Asia. These partnership programmes were all considered successful in increasing parental involvement in learning.

Table 1: Product Characteristics

\begin{tabular}{|c|c|c|}
\hline \multicolumn{3}{|c|}{ Product characteristics } \\
\hline Epstein (2011) approach & UK - TDA (2009) & ISSA (2010) \\
\hline $\begin{array}{l}\text { Based on six types of parental } \\
\text { involvement: parenting, learning at } \\
\text { home, collaborating with the } \\
\text { community, communication, } \\
\text { decision making, volunteering. } \\
\text { - Some kind of action team responsible } \\
\text { for parental involvement. } \\
\text { Clear steps needed to address a goal- } \\
\text { oriented or process-oriented approach. } \\
\text { Characteristics include: incremental } \\
\text { progress, connections to curriculum, } \\
\text { caring and professional development. }\end{array}$ & $\begin{array}{l}\text { - Parenting support - focus } \\
\text { on skills. } \\
\text { - Swift and easy access - } \\
\text { specialist services. } \\
\text { - Community access - } \\
\text { school used as a facility. } \\
\text { - Childcare - support families. } \\
\text { - Varied menu of activities - } \\
\text { outside classroom. }\end{array}$ & $\begin{array}{l}\text { - Promotes partnerships with families and } \\
\text { provides a variety of opportunities for } \\
\text { families and community members to be } \\
\text { involved in children's learning and } \\
\text { development. } \\
\text { - Uses formal and informal opportunities for } \\
\text { communication and information sharing } \\
\text { with families. } \\
\text { - Uses community resources and family } \\
\text { culture to enrich children's development and } \\
\text { learning experiences. }\end{array}$ \\
\hline
\end{tabular}

Although all three programmes share a strong focus on parental involvement in learning, Epstein's approach has too many variables and leans towards a fixed programme and methods, while the TDA's approach might be too broad. ISSA's characteristics focus on partnerships, communication, and resources within the community, and might be a more fitting link to rural multigrade contexts and their unique challenges. Furthermore, if these characteristics help tap parents' capital and develop practicable, contextual-based and effective programmes, they could be considered product characteristics for a SCAF partnership programme for rural multigrade schools.

\section{Research Methodology}

The purpose of this study is to determine the product characteristics of a SCAF partnership programme that would increase parental involvement in learning at rural multigrade schools. The design research process in this study is located in the pragmatist paradigm. Creswell $(2003$, p. 12) maintains that the pragmatic paradigm allows for determining the problem and proposing a solution (change) in order to see what really works and what the best possible solutions are. The pragmatic paradigm creates space for emphasising the rural multigrade context and setting, as well as interacting with and empowering participants, thus providing a broad theoretical lens. This implies that the 'what' they learn during their enquiry will arise out of actions, situations and consequences during the application of what works to solve the problem (Creswell, 2003, p. 11). A qualitative approach was used in this study to determine the opinions and views of the various participants. The qualitative approach makes it possible for a phenomenon to be studied in depth (Bazeley, 2004; Patton, 1990). The qualitative approach in this research allowed for a 'hands-on' study, which increased the likelihood of solving the problem. Data collection methods include primarily observations and focus-group interviews. Points of view, experiences, reactions and insights of parents and teachers indicate characteristics that in turn create partnerships, foster communication, and utilise community resources. The pragmatic paradigm establishes what is practicable, effective and contextual, and ultimately whether there was an increase in parental involvement in learning.

\subsection{Participants}

The Cape Winelands Educational District was randomly sampled from four education districts in the Western Cape, 
South Africa. Two rural multigrade schools were randomly sampled from the rural multigrade schools within the district. The characteristics of these schools are presented in Table 2. All teachers (five) and thirteen randomly sampled parents, across the grades, attended the focus group interviews at School A. All three teachers and thirteen randomly sampled parents, across the grades, attended focus group interviews at School B.

Table 2: Characteristics of Schools A and B

\begin{tabular}{|c|c|c|c|c|}
\hline School & Type and Location & $\begin{array}{c}\text { Teachers (Including } \\
\text { Principal), Learners }\end{array}$ & Grouping of Grades & Parents' Work \\
\hline School A & Rural multigrade & 104 learners & $\begin{array}{c}\text { Grade } R \\
\text { Grade 1 } \\
\text { Grade 2-3 } \\
\text { Grade 4-5 } \\
\text { Grade 6-7 }\end{array}$ & $\begin{array}{c}68 \text { parents were working on } 3 \\
\text { farms. }\end{array}$ \\
\hline School B nearest town & $\begin{array}{c}\text { Rural multigrade } \\
\text { 10km from nearest town }\end{array}$ & $\begin{array}{c}56 \text { learners } \\
3 \text { teachers }\end{array}$ & $\begin{array}{c}\text { Grade } R \\
\text { Grade 1-3 } \\
\text { Grade 4-6 }\end{array}$ & $\begin{array}{c}42 \text { parents were working on 2 } \\
\text { farms. }\end{array}$ \\
\hline
\end{tabular}

\subsection{Workshop}

A combined workshop was held for School A and B: both schools were located near the same town. Fifteen parents and three teachers from each school attended the workshop. Group discussions allowed for interaction between parents and teachers to formulate practicable and contextual strategies for School A and B (Table 3). The researcher organised and led the workshop, with strong support from the two principals. The workshop included the following protocol and content:

- Welcome - What could be expected; emphasise importance of interaction and collaboration.

- Why parental involvement? Focus on the term and then on international videos regarding successful parental involvement in learning at rural schools from similar socio-economic situations.

- Discuss positive aspects and challenges regarding parental involvement at the school in groups; groups indicate their responses.

- Discuss the community - Who is the community? Brainstorm all possible resources in the community in groups; groups indicate responses.

- Present the principles of the SCAF partnership programme. Discuss each principle and brainstorm possible strategies the school could implement the principle. Groups use the previous session's information to create practicable, contextual activities.

- Discuss the implementation of the programme and the roles of programme coordinators.

\subsection{Measuring Instruments and Data Analysis}

Table 3 presents the strategies Schools A and B developed and the data collection methods employed. Data was collected separately at each school. Focus group interviews conducted with parents and teachers comprised semistructured, open-ended questions measuring opinions and perceptions regarding practicability, contexuality and effectiveness of strategies implemented, thus determining how to create partnerships and foster communication, and utilise community resources to increase parental involvement in learning. The degree of effectiveness was measured in terms of who and how many attended the strategy meetings, and the success of implementation of strategies that focused on learning. Observation from a fieldworker, logs, and reports from the principal were also used as data collection methods, which increased the study's credibility. Inductive analysis (McMillan \& Schumacher 2001, p. 462) was employed that allowed categories and patterns to emerge from the data. During Phase One of the analysis, raw data was analysed to determine broad categories related to implementation of strategies at both schools. The second phase of analysis involved identifying themes across categories. Triangulation during data analysis allowed for identification of similarities and validation of data, which also increased the credibility of findings. A fieldworker collected data, which further increased the credibility of findings. Written permission for research was granted by the Western Cape Department of Education. Participation was voluntary and participants were informed that they could withdraw at any point in time. All data was confidential and participants remained anonymous. 
Table 3: Strategies Developed by School A and B with Data Collection Methods

\begin{tabular}{|c|c|c|}
\hline Strategy: & \multicolumn{2}{|l|}{ Data Collection Methods: } \\
\hline Strategy one: Parent evening 1 - Focus on learning (Schools A and B) & Report from school principal indicating views on parent evening 1. & \multirow{5}{*}{ 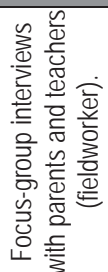 } \\
\hline Strategy two: Family visits school project (School B) & Observation by fieldworker. & \\
\hline $\begin{array}{l}\text { Strategy three: Learners visit parents on farms with focus on learning } \\
\text { (Schools A and B) }\end{array}$ & $\begin{array}{l}\text { Observation from fieldworker. Focus-group interviews with } \\
\text { parents and presenters (fieldworker). }\end{array}$ & \\
\hline $\begin{array}{l}\text { Strategy four: Communication between the school and parents via } \\
\text { SMS. (Schools A and B) }\end{array}$ & Log of messages sent by teachers (principal). & \\
\hline $\begin{array}{l}\text { Strategy five: Parent evening } 2 \text { - Motivation and recognition (Schools } \\
\text { A and B) }\end{array}$ & $\begin{array}{l}\text { Observation from researcher and focus-group interviews } \\
\text { (fieldworker) with parents. }\end{array}$ & \\
\hline
\end{tabular}

\section{Findings and Discussion}

The findings of data gathering are discussed in four themes: creating partnerships with families to provide opportunities to be involved in learning; communication with families on learning; utilising resources in the community that focus on learning; and increased parental involvement in learning. The findings the data collection methods (reports, observations, focus-group interview and log) during and after implementation of strategies are interspersed with quotations from the final focus-group interviews.

\subsection{Create Partnerships and Providing Opportunities to Involve Parents in Learning}

In order to create partnerships between parents and school, and to determine practicable, contextual strategies to increase parental involvement in learning, an interactive workshop was held. The workshop allowed parents and teachers to interact on an equal level. Instead of exercising power over families, working with them to develop relational power to accomplish goals of common interest (Warren, Hong, Rubin \& Uy, 2009) was preferred. When parents and teachers interacted, communicated and collaborated on how to increase parental involvement in learning, guided by a set of principles, they were able to generate contextual strategies. Existing capital (knowledge of their own abilities and context) of parents was tapped and contributed to productive activity and increased knowledge (Hargreaves \& Fullan, 2012, p. 90). The workshop provided ample opportunities for teachers and parents to design their own SCAF partnership programme according to their context and needs. When teachers were asked how they had experienced the workshop, they responded:

The workshop was a real eye-opener to me to see the brilliant, practical ideas that came forward out of discussions. Parents were, for the first time, not quiet. They talked a lot; usually they are very quiet.

The parents were very comfortable, and I personally never thought that parents would get to certain strategies like they did on that day.

The above excerpts show that the teachers from both schools were unanimous in expressing that parents communicated, interacted and collaborated through discussions in order to develop practicable strategies for their schools. Rural multigrade parents were allowed, probably for the first time, to access the knowledge they possessed on how to become more involved in their child's learning. Teachers from both schools indicated a sense of 'surprise' that parents were able to devise practicable strategies to improve parental involvement in learning. Adendorff and Ortell (2011, p. 65) found parents of farm children seemed to be apathetic towards the educational and social needs of their children. Providing them with the opportunity to communicate, interact and collaborate helped to change apathy into interest and enthusiasm. When parents were asked how they experienced the workshop, they responded:

... [We] brainstormed ideas and possible strategies we could use to improve our involvement. It was very successful we could speak openly to say what is good at the school and what we could do to help the school.

Teachers and parents worked together by accessing and utilising their own capital; it was possible to design practicable and contextual strategies to increase parental involvement in learning. The workshop created a sense of shared responsibility (Epstein, 2011, p. 26) towards the increasing parental involvement in learning at their specific school.

Strategies developed contributed towards creating partnerships and providing opportunities to increase parental involvement in learning. According to observation, parent evening 1 - Focus on learning (Strategy one - School A and B), provided parents with an opportunity to become involved with their children's learning and development. Parents and their children were invited to the parent evening where teachers asked parents to talk to their children about what they found 
difficult at school and what their interests were. Teachers then discussed with parents their mutual roles in learning. responded:

During focus-group interviews, when parents were asked how they experienced parent evening 1 , one parent

My one child told me she likes rope skipping so I learned that night we had to use what she likes to improve learning. So I thought about it and then realised that the rope goes higher on different heights so we could then use measurement. She's in Grade 2 so I could use that to explain height.

The teachers of both schools responded:

It was very good where parents and learners communicated with each other. Learners were very eager to tell the parents what they like and what they find difficult.

We are used to [it] that the learners are not involved in parent evening and this time round we involved parents and the learners and it worked very well. It was really effective to see how these parents and learners communicated that night about their work. The children also get the feeling that their parents are interested in them and in their schoolwork.

This strategy provided parents with an opportunity to interact with their children and the teacher about learning. Parents and the learners came together, which therefore allowed single parents to attend the evening. The context was taken into consideration. Parents and teachers agreed, during final focus-group interviews, that partnerships were created during implementation of the strategies:

We communicate a lot better with the school; we really went into a partnership to make things better. (Parents)

The attendance of parents in their own right already pointed towards a partnership between the school and the parents;

we can see the support is there. (Teachers)

Through focusing on partnerships, opportunities arose for parents and teachers to become more involved in learning. The quality and quantity of interactions among parents, teachers and learners during these opportunities further indicated the need to create partnerships and provide opportunities for parents to become actively involved in their child's education.

\subsection{Create Formal and Informal Opportunities to Communicate about Learning}

At the workshop it was apparent that a faster, more effective method of communication was needed than the traditional letter to involve parents in learning. Since most parents have cell (mobile) phones, a system was implemented to communicate information (Strategy four - School A and B) about learners' learning instantly to parents via Short Message Service (SMS). This increases communication, interaction and collaboration between school and parents, and between parents and learners. The log of messages clearly indicates a focus on learning and providing parents with access to information and support, to collaboratively increase parental involvement in learning.

School B sent 42 messages and School A sent 54 messages during the six-month implementation of the SCAF partnership programme. These messages included general communication and communication regarding learning. Below are a few of the examples that focused on learning:

- Please remember that your child is writing a mathematics test tomorrow. (School B)

- Please support your child in answering the mathematics exercise; he or she must just write the answers. (School A)

At focus group interviews, teachers and parents from both schools (Strategy four) found that the messages through the SMS system improved communication, not only in learning, but also in general. Its implementation was therefore successful. Parents said:

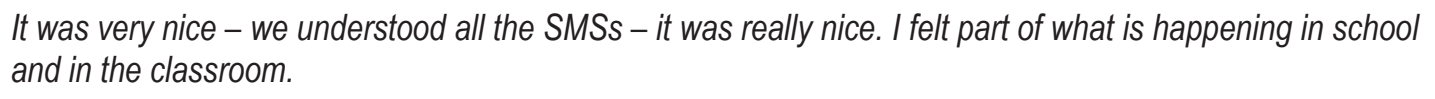

The teacher agreed:

A definite winner - could not have asked for something better. The communication is easier and a lot better; the parents also replied very well.

Parents were involved in learning through a 'digital presence' in class and the 'digital interaction and 
communication' allowed parents at work to be involved in learning. This type of communication provided parents with an opportunity to interact and collaborate with their children at home regarding what happened in class that day. This strategy added to their sense of being expected to support their children with learning at home and also with a sense of obligation and feeling of trust in fulfilling a role.

To further enhance communication regarding learning and the role of the parent, a recognition and motivation evening was held. A motivational speaker conveyed a message regarding the importance of parents and learning. Teachers prepared a certificate for each learner. On the certificate the teacher wrote something positive about the learner in general and about learners' learning. Parents had the opportunity to present the certificate to their child/children. Parents and teachers enjoyed a meal afterwards, which allowed time for informal communication. During the focus group interview, parents expressed their experiences of the evening:

To motivate the child and parents - to build self-confidence - to know we can make a success out of our lives. I was very proud of my child up on the stage. I could not stop crying, because I never experienced that when I was at school. I could see my child is getting a chance and I really was in the clouds that night and could not stop talking about it. I am really looking forward to my child's future and I know now I need to do a lot to help her.

Teachers agreed and stated:

We got the feeling of recognition. The parents felt part of the school and they felt very proud. It was a very good strategy. We also concentrated on the positive side in order to motivate them. That really meant a lot to them. Very positive, and it was great to have everybody there - a true community feeling.

This strategy conveyed a message of motivation and recognition through communication between parents, the school, the community and the learners.

\subsection{Utilise Community and Family Resources to Enrich Children's Learning Experiences}

In order to utilise community and family resources, both schools visited the farms where parents worked. These parents acted as presenters during lessons for learners on the farm. Teachers allowed parents to share their knowledge within a lesson. During the focus-group interviews (Strategy three - Farm visits from School A and B), presenters were asked how they experienced being part of the learning process:

\footnotetext{
Yes, it felt we were part of the learning process and that we were the teachers today. We would like more of this kind of contact and lessons. They enjoyed it and learned a lot.

I felt the learners opened up to me; they did not see me as a teacher. I think in that case they listened more than, for instance, to the teacher.

Parents felt part of the learning process and participated in a successful strategy. It is important to note that some parents were asked to be presenters but were illiterate. They were able to be part of the lesson due to the knowledge they possessed, for instance, on pruning vineyards. The parents therefore supported learners through their interaction in the learning process.
}

Another strategy that successfully utilised community and family resources was inviting parents to class, to be part of a lesson. During observation of Strategy two (School B), where a parent was part of a lesson at school, the field worker highlighted following:

The teacher of the Grade 1, 2 and 3 combined classes invited a parent to participate in a lesson where she had to talk to the learners about how things had changed since she was at school. The parent had concrete evidence like coins from the past, and learners were given the chance to look at and touch the coins. The learners were given the opportunity to ask questions which they freely did; she answered the questions confidently. The learners were very excited when she promised to visit them again and would show them how they used to bake bread in the old days.

Parents who participated in a lesson at school again played an important role in the learning process. Learners had never before experienced a parent participating in a lesson at school. The parent had to prepare to present a lesson and therefore had an obligation towards the learning process. During the interview the family member highlighted she felt part of the learning process.

Yes I definitely felt that I was part of the learning process.

The teacher agreed and stated:

She was definitely part of the learning process; the learners learned a lot today.

As the parent was part of the learning process and presented the knowledge and experience she possessed, she was utilised as a resource. 


\subsection{Increased Parental Involvement}

It is axiomatic that if the data presented an increase in parental involvement through the strategies implemented, then the strategies were practicable, effective and contextual.

All the teachers at the schools (School B: 5 and School C: 3), as well as all the learners (School B: 104 and school C: 56) and most of the parents (School B: 61 and School C: 35) attended parent evening 1.

Principals also commented positively on the high attendance in their reports.

It was very interesting to see how many parents attended, especially the dads; they never [previously] came. The parents are willing to help and want to be more involved.

Both parent evening 1 and the recognition and motivation evening were well attended. According to observations at the recognition evening (Strategy five - School A and B), all learners and teachers of both schools attended the evening; a total of 108 parents also attended the evening. Improved attendance allowed parents a chance to utilise their social capital.

During the final focus-group interviews, parents and teachers agreed that implementation of the strategies had been successful.

Successful, the programme gave you an opportunity to see how we can help the children to learn. (Parents)

'The programme was very successful.' (Teachers)

Parental involvement in learning increased at both schools, and was acknowledged by parents and teachers as successful.

\section{Conclusion}

Education is the great engine of personal development. It is through education that a child of farm workers can become the president of a great nation. It is what we make out of what we have, not what we are given, that separates one person from another (Nelson Mandela).

The findings indicate that, in order for rural multigrade schools to increase parental involvement in learning, certain product characteristics should be focused on within a SCAF partnership programme. These product characteristics include: promoting partnerships with parents to create opportunities to involve parents in learning; creating formal and informal opportunities for communication regarding learning; and utilising community and parents as resources to enrich children's learning. This study further concludes that parents and teachers need to focus on these characteristics and the existing challenges in the multigrade milieu when developing a SCAF partnership programme at a workshop. This will then lead to the development of practicable, contextual and effective strategies for that specific school.

\section{References}

Adendorff, S., \& Ortell, P. (2011). The rural gap: Farm labourers' potential to extend the educator's hand. South African Rural Educator, 1, 56-67, December.

Amoateng, A.Y., Richter, L.M., Makiwane, M., \& Rama, S. (2004). Describing the structure and needs of families in South Africa: Towards the development of a national policy framework for families. A report commissioned by the Department of Social Development. Pretoria: Child Youth and Family Development, Human Sciences Research Council.

Bayat, A., Louw, W., \& Rena, R. (2014). The impact of socio-economic factors on the performance of selected high school learners in the Western Cape Province, South Africa. Journal of Human Ecology, 45(3), 183-196.

Bazeley, P. (2004). Issues in mixing qualitative and quantitative approaches to research. In R. Buber, J. Gadner, \& L. Richards (Eds.), Applying qualitative methods to marketing management research (pp. 141-156). Basingstoke: Palgrave Macmillan.

Bloch, G. (2009). The toxic mix: What's wrong with South Africa's schools and how to fix it. Cape Town: Tafelberg.

Blum, N., \& Diwan, R. (2007). Small, multigrade schools and increasing access to primary education in India: National context and NGO initiatives. Brighton: CREATE.

Boonzaaier, P. J. V. (2008). Multi-grade rural schools intervention in the West Coast Winelands EMDC: A case study. (Unpublished doctoral thesis). Cape Peninsula University of Technology. Wellington, South Africa.

Colbert de Arboleda, C. V. (2010). Fundación Escuela Nueva. Paper presented at the 2010 Southern African Multigrade Education Conference, Wellington, South Africa, 22-24 March 2010.

Creswell, J. W. (2003). Research design: Qualitative, quantitative and mixed methods approaches (2nd ed.). Thousand Oaks, CA: Sage.

Education Policy Consortium. (2011). Research report: Teaching literacy and numeracy in multigrade classes in rural and farm schools in South Africa. Johannesburg: Centre for Education Policy Development (CEPD); Centre for Education Rights \& Transformation 
Epstein, J. L. (2009). School, family, and community partnerships: Your handbook for action (3rd ed.). Thousand Oaks, CA: Corwin.

Epstein, J. L. (2011). School, family and community partnerships: Preparing educators and improving schools. Boulder, CO: Westview Press.

Epstein, J. L., \& Sheldon, S. B. (2006). Moving forward: Ideas for research on school, family, and community partnerships. In C. F. Conrad, \& R. Serlin (Eds.), SAGE handbook for research in education: Engaging ideas and enriching inquiry (pp.117-137). Thousand Oaks, CA: Sage.

Fan, X. T., \& Chen, M. (2001). Parental involvement and students' academic achievement: A meta-analysis. Educational Psychology Review, 13(1), 1-22, March.

Ferlazzo, L. (2011). Involvement or engagement. Educational Leadership, 68(8), 10-14.

Fuller, M. L. (2008). Poverty: The enemy of children and families. In G. Olsen, \& M. L. Fuller (Eds.), Home-school relations: Working successfully with parents and families. (3rd ed.) (pp. 257-272). Boston, MA: Pearson.

Hamunyela, M. N. (2008). A critical analysis of parental involvement in the education of learners in rural Namibia. (Unpublished doctoral dissertation). University of Pretoria, South Africa.

Hanushek, E. A., \& Wössmann, I. (2007). Education quality and economic growth. Washington DC: World Bank.

Hargreaves, A., \& Fullan, M. (2012). Professional capital: Transforming teaching in every school. New York, NY: Teachers College Press.

Henderson, A. T., \& Berla, N. (Eds.). (1994). A new generation of evidence: The family is critical to student achievement. Washington, DC: National Committee for Citizens in Education.

Henderson, A., \& Mapp, K. L. (2002). A new wave of evidence: The impact of school, family, and community connections on student achievement. Austin, TX: Southwest Educational Development Laboratory.

Ho, E. S. (2009). Educational leadership for parental involvement in an Asian context: Insights from Bourdieu's theory of practice. School Community Journal, 19(2), 101-122.

International Step by Step Association. (2010). Competent educators of the 21st century: Principles of quality pedagogy. [Online] Available: http://www.issa.nl/docs_pdfs/Quality-Principles-final-WEB.pdf (June 23, 2011).

Jeynes, W. H. (2003). A meta-analysis: The effects of parental involvement on minority children's academic achievement. Education and Urban Society, 35(2), 202-218, February.

Jeynes, W. H. (2005). A meta-analysis of the relation of parental involvement to urban elementary school student academic achievement. Urban Education, 40(3), 237-269, May.

Jeynes, W. H. (2011). Parental involvement and academic success. New York, NY: Routledge.

Jordaan, V., \& Joubert, J. (2008). Training of teachers in poor rural areas through a multigrade intervention to achieve development goals: Our experience of using ODL as a tool for building capacity and what lesson can be learned? Paper presented at the Fifth Pan-Commonwealth Forum on Open Learning: Access to Learning for Development, London, 13-17 July 2008.

Little, A. W. (1995). Multi-grade teaching: A review of research and practice. London: Overseas Development Administration, Education Division.

Little, A. W. (2005). Learning and teaching in multigrade settings. Paper prepared for the UNESCO 2005 EFA Monitoring Report. Paris: UNESCO.

Little, A. W., Pridmore, P., Bajracharya, H., \& Vithanapathirana, M. (2006). Learning and teaching in multigrade settings (LATIMS). Technical report. London: Department for International Development (DFID).

McMillan, J. H. \& Schumacher, S. (2001). Research in education: A conceptual introduction (5 ${ }^{\text {th }}$ ed.). New York, NY: Addison Wesley Longman.

Patton, M. Q. (1990). Qualitative evaluation and research methods (2nd ed.). Newbury Park, CA: Sage.

Rao, Y. (2010). Community-based education at River Rishi Valley. Paper presented at the 2010 Southern African Multigrade Education Conference, Wellington, South Africa, 22-24 March 2010.

Statistics South Africa. (2010). Social profile of South Africa, 2002-2009. [Online] Available: http://www.statssa.gov.za/publications/ Report-03-19-00/Report-03-19-002009.pdf (November 17, 2010).

Taole, M. J. (2014). Quality basic education for all: Challenges in multi-grade teaching in rural schools. Mediterranean Journal of Social Sciences, 5(1), 531-536.

TDA see Training and Development Agency for Schools.

Training and Development Agency for Schools. (2009). What are extended services? [Online] Available: http://www.tda.gov.uk (April 15, 2011).

UNESCO. (2007). Education for all global monitoring report 2008. Paris: UNESCO; Oxford: Oxford University Press.

UNESCO. (2012). Education for all global monitoring report 2012: Youth and skills: Putting education to work. Paris: UNESCO.

Van Wyk, N., \& Lemmer, E. M. (2009). Organising parent involvement in South African schools. Cape Town: Juta.

Venter, N. V. (2013). Parental involvement in learning at rural multigrade schools in South Africa: A school, community and family partnership programme. (Unpublished doctoral thesis). Cape Peninsula University of Technology, Wellington, South Africa.

Wandersman, A. Motes, P.S., Lindsay, R.E., Snell-Johns, J. Ford, L., \& Amaral, D. (2002). South Carolina parent involvement instrument report: Final report submitted to South Carolina Education Oversight Committee. Columbia, SC: Submitted to the South Carolina Education Oversight Committee by the Institute for Families in Society.

Warren, M. R., Hong, S., Rubin, C. L., \& Uy, P. S. (2009). Beyond the bake sale: A community-based relational approach to parent engagement in schools. Teachers College Record, 111(9), 2209-2254, September. 